\title{
DESCRIPTIONS OF NEW SPECIES OF AUSTRALIAN LEPIDOPTERA, WITH NOTES ON SYNONYMY.
}

\author{
By Oswald B. Lower, F.E.S., \&c.
}

\section{BOMBYCINA.}

\section{LIM ACODID $\mathbb{E}$.}

\section{DORATIPHORA BRACHYOPA, n.sp.}

§. $25 \mathrm{~mm}$. Head, palpi, and collar dark reddish, face ochreous. Thorax and abdomen ochreous, tinged with fuscous-reddish, thorax lighter in middle. Antennæ ochreous, pectinations at greatest length $1 \frac{1}{2}$, closely set. Legs deep reddish-fuscous, densely haired. Thorax beneath densely haired with ashy-greywhitish. Forewings rather short, costa hardly arched, hindmargin somewhat bowed; dull silvery-whitish, basal two-thirds occupied by a deep reddish patch, somewhat obscure above inner margin, outer edge somewhat convex, with a fine darker fuscous marginal line; this line is continued right round the patch, but causes a sharp indentation above inner margin at $\frac{2}{3}$ from base; an obscure ochreous discal dot ringed with deep reddish at about $\frac{2}{3}$ above middle of disc; a fine blackish line from $\frac{5}{6}$ of costa to anal angle, strongly dentate on lower $\frac{3}{4}$, almost straight on upper fourth; a fine blackish hindmarginal line more or less interrupted on veins: cilia ashy-grey-whitish with a fine obscure darker line. Hindwings reddish-ochreous, with a darker line along hindmargin; cilia as in forewings.

Cairns, Queensland; two specimens in November.

\section{Scoliacma (?) xanthodelta, n.sp.}

๙. $20 \mathrm{~mm}$. Head, palpi, collar, and abdomen yellow, abdomen infuscated. Thorax leaden-fuscous. Legs yellowish mixed with fuscous. Forewings elongate-triangular, costa somewhat sinuate 
in middle, arched towards apex, apex rounded, hindmargin obliquely rounded; leaden-fuscous, markings dull yellow; a small basal patch, outer edge oblique, continued as a fine costal line throughout; a moderate triangular patch on costa beyond middle, beneath which is a moderate roundish spot: cilia leaden-fuscous. Hindwings light yellow; a broad fuscous hindmarginal band, becoming constricted at anal angle; cilia pale yellow.

Broken Hill, N.S. Wales; two specimens (at light) in September.

The insect under notice is doubtfully referable to Scoliacma.

\section{Sorocostia monozona, n.sp.}

q. $17 \mathrm{~mm}$. Head, thorax, and abdomen ashy-grey-whitish, antennæ fuscous, (palpi broken). Legs fuscous, ringed with white. Forewings elongate, moderate, dilated posteriorly; ashy-greywhitish, costa irregularly edged with fuscous throughout; a welldefined short thick black outwardly oblique streak from costa at $\frac{1}{3}$ to middle of disc, ending on second tuft of scales; a faint similar line from middle of costa, extremity lost in general groundcolour; a third similar line from before apex, hardly perceptible; veins towards hindmargin irregularly irrorated with blackish: cilia ashy-grey-whitish. Hindwings fuscous-grey, becoming darker round apex; cilia pale grey, slightly infuscated round apex.

Blackwood, South Australia; two specimens in November.

Mr. Meyrick, to whom this and the following species were submitted, returned them as unknown to him.

\section{Sorocostia Platygona, n.sp.}

ㅇ. $20 \mathrm{~mm}$. Head, thorax, abdomen, palpi, and legs white, palpi 2, terminal joint very short, legs dusted with blackish. Forewings elongate-triangular, costa gently arched, hindmargin bowed, oblique; white; tufts white, anteriorly slightly infuscated; an obscure fuscous dot on costa near base; a second more distinct on costa at $\frac{1}{5}$ from which proceeds an outwards-curved twice 
sinuate fine fuscous line to inner margin at $\frac{1}{4}$; three minute black dots on costa in middle; a well-defined broad outwardly oblique fascia from $\frac{3}{5}$ of costa to middle of disc, thence continued obliquely inwards to just beyond middle of inner margin, outer edge more or less strongly edged with black; a thick irregular outwardscurved pale fuscous irregularly waved line from just before apex to just before anal angle; a few fuscous scales before hindmargin; a blackish hindmarginal line: cilia whitish. Hindwings white, slightly infuscated on apical portion; cilia white, with an indistinct grey line at base.

Mackay, Queensland; one specimen in December. It is an easily recognised species by the $>$-shaped fascia.

\section{Anestia trissodesma, n.sp.}

5. $16 \mathrm{~mm}$. Head, antennæ, palpi, thorax, abdomen and legs dark fuscous, more or less finely dusted with white, patagia whitish. Forewings elongate-triangular, strongly dilated, costa gently arched posteriorly, hindmargin obliquely rounded; fuscous; three moderately broad whitish transverse fasciæ; 1st from $\frac{1}{4}$ of costa to $\frac{1}{4}$ of inner margin, becoming blotch-like on costa, narrowed on lower $\frac{2}{3}$; 2nd from beyond middle of costa to middle of inner margin, outer edge marked by an irregularly dentate or waved line; 3rd narrowed from just before apex to anal angle, with a slight indentation above and below middle, and becoming broader at anal angle; space between 2nd and 3rd fasciæ pale bluish, excepting upper $\frac{1}{3}$, which is fuscous: cilia fuscous, tips darker. Hindwings clear orange, becoming slightly fuscous around apex; cilia fuscous, along inner margin yellowish.

Broken Hill, N.S. Wales; one specimen (at light) in June.

\section{GEOMETRINA.}

\section{HYDRIOMENIDE.}

Mesoptila anthracias, n.sp.

ઈ. $24 \mathrm{~mm}$. Head, palpi, antennæ, thorax, and abdomen dark fuscous, palpi five times breadth of eye. Antennal ciliations $1 \frac{1}{2}$. 
Legs fuscous-whitish, tibiæ and tarsi blackish, ringed with ochreous-whitish. Forewings elongate-triangular, costa nearly straight, hindmargin bowed, waved; dark fuscous, mixed with blackish; a raised tuft of blackish scales in middle of disc; a ridge-like tuft of similar scales towards base near inner margin; an obscure thick fuscous curved line from about $\frac{1}{4}$ of costa to $\frac{1}{4}$ of inner margin; a small pale yellow cuneiform spot on costa at about $\frac{3}{4}$, from which proceeds a dentate double fine black lin $\mathrm{e}$ curved outwards and ending on inner margin at $\frac{3}{4}$; the ground colour on costa beyond the yellow spot much darker, the anterior portion of the double black line not reaching costa, but deflected downwards and continued as a black interrupted line just beneath costa to near base, obscure towards base; veins towards hindmargin neatly outlined with black, each with a minute yellow spot at hindmarginal extremity: cilia dark reddish-fuscous. Hindwings with hindmargin rounded, crenulate; dark fuscous, becoming lighter on median third; an erect (seemingly expansible) tuft of scales in middle of disc; three well defined wavy black lines from middle of inner margin, two upper terminating in tuft of scales, lower one curved outwards and continued to costa at about $\frac{2}{3}$; cilia as in forewings, hairs on inner margin whitish.

This is the second species recorded from Australia. Meyrick was unacquainted with the male and consequently could not give the characters in full; the additional generic characters will therefore read:-Antennal ciliations of the male $1 \frac{1}{2}$, palpi porrected, about 5, second joint loosely haired, terminal joint distinct, somewhat claviform, and slightly recurved. The forewings appear to have three tufts of scales, one at about $\frac{1}{3}$ from base in middle, a larger one in middle of disc, and a ridge-like patch towards base near inner margin. The long palpi give the species a most curious and distinct appearance. It is not like Hydriomena brugata, Gn., at first sight.

Sale, Victoria. The single specimen is in the collection of Mr. G. Lyell, Junr., of Gisborne, Victoria. 


\section{Heterochasta lasioplaca, n.sp.}

3. $30 \mathrm{~mm}$. Head, antennæ, palpi, thorax, and abdomen fuscous, palpi about $1 \frac{1}{2}$, snow-white at base beneath and at apex of terminal joint, terminal joint about $\frac{1}{2}$ length of second. Antennal ciliations $\frac{1}{4}$. Abdomen with pairs of dark fuscous spots on segments. Legs ochreous-whitish, banded with fuscous. Forewings elongate-triangular, hindmargin hardly waved, bowed, oblique; dull fuscous-greenish, with numerous waved darker fuscous transverse lines; outer edge of basal patch indicated by a moderately thick correlated band, slightly sinuate outwards above middle, from about $\frac{1}{8}$ of costa to $\frac{1}{5}$ inner margin; median band formed by two dark fuscous bands of three lines each, separated by a clear snow-white space, becoming light ferruginous on lower $\frac{1}{2}$; anterior edge from just beyond $\frac{2}{5}$ of costa to middle of inner margin; posterior edge from before $\frac{3}{4}$ of costa to $\frac{3}{4}$ of inner margin, with a strong sharp projection in middle and a less prominent one above middle, followed throughout more or less by a fine whitish line; a black lunate discal mark in the white space above middle touching anterior edge of band, subterminal and submarginal lines waved, irregular, blackish, a fine blackish hindmarginal line separated into small spots by minute white spots at extremities of veins : cilia ochreous-grey barred with black. Hindwings with the hindmargin rounded; dull leaden becoming paler towards base; cilia as in forewings.

Brisbane, Queensland; one specimen. Distinct by the hindwings and snow-white spot of forewings.

\section{STERRHID压.}

Sterrha Rhodocosma, n.sp.

ิิ. $24 \mathrm{~mm}$. Head, face, palpi, and thorax rosy-carmine, abdomen whitish. Antennæ ochreous, pectinations at greatest length 2 . Legs fuscous, anterior coxæ tinged with rosy-carmine, posterior pair ochreous-whitish. Forewings triangular, costa nearly straight, apex rounded, hindmargin obliquely bowed; pale whitish-ochreous, thickly irrorated with rosy-carmine, so as to appear rosy-carmine, 
three darker rosy-carmine darker transverse fasciæ; 1st from base to $\frac{1}{5}$, outer edge nearly straight, somewhat waved, indicating basal patch; 2nd broad from about middle of costa to middle of inner margin, indicating median shade; 3rd narrow, waved from costa at $\frac{2}{3}$ to inner margin near anal angle; an obscure rosy-carmine dot above middle, midway between last two fasciæ; subterminal and submarginal lines darker carmine, thick and indistinet: cilia pale ochreous, suffusedly mixed with rosy-carmine. Hindwings pale whitish-ochreous; two obscure fuscous transverse median bands, hardly perceptible in some specimens; cilia pale whitish-ochreous.

Torrens Island and Semaphore, South Australia; beaten from Salicornia arbuscula in October.

A distinct and beautiful species taken by Mr. Harold Lower. The lustre of the forewings of this species when fresh is magnificent, but after death this fades to a dull rosy-carmine.

\section{MONOCTENIADE.}

\section{Mnesampela petrochroa, n.sp.}

ㅇ. $33 \mathrm{~mm}$. Head, thorax, and antennæ greyish-ochreous, abdomen white with minute black scattered scales; five or six pairs of black dots placed laterally on underside at juncture of each segment. Legs whitish, anterior tibiæ and tarsi ringed with blackish, palpi blackish. Forewings triangular, apex prominent, hindmargin slightly bowed; light greyish-ochreous, with fine indistinct irregular fuscous strigulæ; costa very finely whitish, strigulated with fuscous; an indistinct blackish suffusion on costa at base; a curved series of five small black dots, one on costa at $\frac{1}{6}$, two close together immediately below, one in middle, and one above inner margin; an almost straight series of similar dots, edged posteriorly with white and placed on a pale ferruginous shade, from before apex to about $\frac{1}{3}$ of inner margin: cilia silverywhite, a pale ferruginous indistinct line along inner margin and more or less continued along basal half of cilia to near apex. Hindwings greyish-fuscous, somewhat purplish-tinged, becoming greyish-ochreous towards inner margin, hairs on inner margin 
white; cilia and markings as in forewings, but dots not placed on ferruginous shade.

Hoyleton, South Australia; one specimen taken by Mr. E. Guest in May.

\section{NOCTUINA,}

\section{Praxis macropa, n.sp.}

ई-o. 40, $42 \mathrm{~mm}$. Head, palpi, and thorax reddish-ochreous, thorax in middle grey-whitish, abdomen grey. Antennæ ochreous; ciliations about 6 at greatest breadth. Legs fuscous, posterior pair pinkish-white. Forewings moderate, elongate, dilated posteriorly; costa arched at base, thence nearly straight, apex rounded, hindmargin obliquely rounded; ashy-grey, mixed with reddishochreous and finely irrorated with black and dark fuscous; a fine black strongly thrice dentate line from about $\frac{1}{4}$ of costa to $\frac{1}{3}$ inner margin; a pale ochreous elongate spot, finely edged with black, touching middle dentation of first mentioned line; a larger more reddish similar spot above and slightly beyond, also edged with black; a reddish-ochreous reniform spot edged with black at end of cell; a strongly dentate black line from beneath costa at about $\frac{4}{5}$ to $\frac{2}{3}$ of inner margin, edged posteriorly by its own width of pale ochreous-reddish; a similar but lighter parallel line (indicating subterminal) near and beyond from costa at $\frac{5}{6}$ to anal angle, interspace bright reddish-ochreous : cilia ochreous-reddish, chequered with blackish. Hindwings fuscous-grey; cilia grey-whitish, reddish-tinged on basal $\frac{1}{2}$.

Broken Hill, N.S.W.; three specimens taken at electric light in May.

The antennal pectinations of this species are so filiform that they curl up into an inextricable mass when the insect is dry; they can, however, be readily rearranged by relaxing.

Acontia cyanipha, n.sp.

5. $28 \mathrm{~mm}$. Head and thorax white. Antennæ fuscous, ciliations $\frac{1}{2}$. Abdomen ochreous-yellow. Legs and palpi fuscous, tibiæ ringed with white. Palpi strongly recurved, second joint 
whitish externally. Forewings elongate, dilated posteriorly, costa nearly straight, hindmargin obliquely rounded; white, slightly ochreous-tinged; a fine blackish dot at base in middle; two narrow elongate, partly connected, fuscous spots along costa, extending from base to before middle and followed on costa by a pale fuscous suffusion to $\frac{3}{4}$, terminated by a small dark fuscous spot; a large erect irregular somewhat cuneiform bluish-fuscous patch; from inner margin before anal angle to more than $\frac{1}{2}$ across wing, apex obtuse; a narrow inwards-curved whitish-ochreous discal lunule, finely edged with black; a moderate somewhat rhomboid pale bluish patch immediately beyond, containing two black teeth, their apices directed inwards, on posterior edge, below which the bluish colour is continued as an irregular streak to anal angle, hindmarginal area beyond chocolate, with a suffused patch of ground-colour on costa; a hindmarginal row of dentate black dots edged posteriorly by fine dots of ground-colour : cilia chocolate, tips mixed with whitish. Hindwings pale yellow, broadly suffused with light fuscous round hindmargin; cilia yellowish-ochreous with a fuscous parting line, except towards anal angle.

Broken Hill, N.S. Wales; one specimen in January.

\section{Britha (?) Cosmopis, n.sp.}

q. $23 \mathrm{~mm}$. Head, palpi, and anterior legs fuscous, antennæ ochreous. Thorax ochreous-fuscous, median third silvery-white. Abdomen yellow, becoming ochreous-whitish on anterior segments. Forewings triangular, costa nearly straight, hindmargin hardly bowed; ochreous-fuscous; a thick dull leaden-metallic streak along costa from base to apex, attenuated posteriorly, shaded beneath by more than its own width with light ochreous, suffused at extremities; a very broad silvery-white streak along inner margin from base to anal angle, suffused with pale ochreous along extreme inner margin and edged above by a line of darker ochreous-fuscous; two small silvery-white cuneiform spots just above extremity of this streak, upper one largest; a fine curved blackish line from beneath costa just below apex to upper extremity of silvery-white streak; hindmarginal area beyond bluish-leaden with a faint 
whitish median line; a fine blackish line terminating before hindmargin : cilia bluish-leaden with two darker parallel lines. Hindwings bright orange-yellow, with a broad blackish hindmarginal band, attenuated above apex; cilia greyish-ochreous with a black median line well defined.

Cape York, Queensland; two specimens in January.

\section{PYRALIDINA.}

\section{BOTYDID ES.}

\section{Metallarcha zygosema, n.sp.}

ㅇ. $20 \mathrm{~mm}$. Head and thorax whitish-yellow, abdomen yellowish, antennæ, palpi, and legs fuscous, posterior legs ochreous. Forewings elongate-triangular, light brown, with pale yellow markings outlined with darker brown; a large irregular cuneiform patch from base below costa to just before $\frac{1}{3}$ of wing, its lower edge emitting a long slender streak along inner margin to anal angle, posteriorly attenuated; a large irregular lunate mark in middle of wing, connected with basal patch anteriorly by a short bar, very strongly indented on middle portion, upper extremity obtuse, lower acute; a rather broad irregularly edged curved fascia from costa just before apex to inner margin above anal angle but not quite reaching it, anterior edge with a slight projection below middle; a narrow yellowish hindmarginal line: cilia pale yellow, deeper at base. Hindwings pale fuscous, with a pale yellow basal patch sending a projection from below middle towards inner margin; an indistinct elongate black spot in yellow patch; cilia pale yellow, deeper at base.

Hoyleton, S.A.; one specimen (Coll. E. Guest) in December. The specimen is somewhat abraded, consequently the description may require some latitude for comparison.

\section{SCOPARIAD正.}

Scoparia lichenopa, n.sp.

א-o. 18, $21 \mathrm{~mm}$. Head, palpi, thorax, antennæ, and legs ashy-grey-whitish, posterior legs grey-whitish, abdomen grey, three 
anterior segments orange-yellowish. Forewings moderate, elongate, gently dilated; ashy-grey-whitish; markings black, suffused; a narrow outward-curved fascia from about $\frac{1}{4}$ of costa to $\frac{1}{4}$ of inner margin, a fine line along median fold from base to fascia but hardly reaching it; a very oblique irregular fascia from costa before apex to about $\frac{2}{3}$ of inner margin, almost obliterated by ground-colour in some specimens; a small rounded white spot at end of cell, edged more or less with blackish; a hindmarginal row of black teeth: cilia ashy-grey-whitish with blackish points. Hindwings greyish-fuscous, becoming lighter towards base; cilia greyish-fuscous.

Broken Hill, N.S. Wales; four specimens in April and May. The present species is somewhat allied to polysticha, Lower.

\section{TINEINA.}

\section{ECOPHORIDE.}

\section{Philobota xanthocoma, n.sp.}

¡ิ--‥ 13, $15 \mathrm{~mm}$. Head, palpi, antennæ, thorax, and abdomen dark fuscous, anal tuft yellow. Legs dark fuscous, tibiæ and tarsi with yellowish bands. Forewings moderate, costa hardly arched, apex rounded, hindmargin obliquely rounded; dark fuscous with yellowish markings; a moderate irregular spot on costa about middle, immediately preceded by two small round black dots; a similar yellowish spot on costa at about $\frac{3}{4}$, and another more obscure immediately below on anal angle, separated in middle of wing by a line of ground-colour, with an obscure black spot at extremity; an irregular thick streak along hindmargin, with a projection inwards in middle: cilia dull fuscous tinged with ochreous around anal angle. Hindwings dark fuscous; cilia yellow, becoming fuscous round apex.

Semaphore, S.A.; several specimens taken by Mr. Harold Lower in September. The cilia of the hindwings are a good distinction.

Linosticha CREmNodisema, n.sp.

ふิ-o. 13, $18 \mathrm{~mm}$. Head dull ochreous. Thorax fuscous. Antennæ, legs, and palpi fuscous, palpi greyish internally, middle 
and posterior legs ochreous. Forewings moderate, costa gently arched, apex rounded, hindmargin obliquely rounded; dull fleshy ochreous, minutely irrorated with black scales which tend to coalesce and obliterate the markings; an obscurely marked double black dot in disc just before middle; a similar but more distinct one in a line with first just beyond middle, beneath which the blackish scales coalesce and appear to form a more or less ill-defined blackish suffusion : cilia fuscous mixed with fleshyred. Hindwings greyish-fuscous; cilia greyish.

Broken Hill, N.S. Wales; two specimens (at light) in April. An obscure species.

\section{Compsotropha habrodelta, n.sp.}

q. $16 \mathrm{~mm}$. Head, palpi, and thorax snow-white, thorax with a narrow dark fuscous anterior band. Legs ochreous-whitish, anterior pair fuscous, tarsi ringed with white; abdomen greyish. Antennæ fuscous, basal joint white beneath. Forewings moderate, hardly dilated, costa nearly straight, apex rounded, hindmargin obliquely rounded; snow-white; costal edge posteriorly ochreous; a narrow black oblique fascia close to base, somewhat dilated on costa; a narrow oblique irregular orange fascia from costa at $\frac{3}{4}$ to middle of inner margin, edged on both sides with black, narrowed on costa; a similar short fascia from anal angle to middle of posterior edge of previously mentioned fascia, becoming blackish on anal angle and enclosing a spot of ground-colour on inner margin; a narrowed suffused blackish hindmarginal streak, not reaching anal angle: cilia ochreous-orange, strongly mixed with blackish. Hindwings with apex somewhat pointed; light greyishfuscous; cilia pale yellow.

Gisborne, Victoria; one specimen in February (Coll. G. Lyell, Junr.). Near xanthodelta, Meyr.

\section{Cegsyra habropis, n.sp.}

๙. $20 \mathrm{~mm}$. Head and palpi orange-yellow. Legs, thorax, abdomen, and antennæ purplish-fuscous, posterior legs orangeyellow. Forewings moderate, costa gently arched, apex round- 
pointed, hindmargin obliquely rounded; bright orange-yellow; a thick fuscous-purple basal patch continued along costa to slightly beyond middle, posteriorly attenuated, a very broad fuscous-purple hindmarginal band occupying apical third of wing, edged anteriorly by a waved, indented in middle, darker fuscous line; the central portion of band is occupied by a bright rosy-purple patch : cilia fuscous-purple. Hindwings bronze-yellow ; cilia fulvous, darker at base.

Near Rockhampton, Queensland; one specimen in November. Nearest seleniaca, Meyr.

\section{Cegsya grammophora, n.sp.}

5. $15 \mathrm{~mm}$. Head, palpi, and thorax orange, antennæ blackish, ciliations 1; legs ochreous, anterior and middle pair infuscated; abdomen dark fuscous, anal tuft orange. Forewings moderate, costa gently arched, apex hardly pointed, hindmargin obliquely rounded; yellow; markings black, a thick basal fascia, its outer edge hardly curved; a thick somewhat oblique fascia from before middle of costa to middle of inner margin; dilated on lower half; a similar fascia from about $\frac{3}{4}$ of costa to anal angle, connected above middle by a fine irregular line from middle of former fascia; a fine blackish hindmarginal line joining fascia at anal angle, the markings, with the exception of basal fascia, forming the letter W on wing, the yellow spaces on costal and inner margin tinged with orange : cilia blackish on costa and on anal angle orange. Hindwings fuscous, lighter towards base; cilia fuscous.

Gisborne, Victoria; one specimen on dry grass at dusk in January.

At first sight not unlike a dwarfed specimen of Peltopleora argutella, Zeller. The curious W-shaped mark on the forewings is a very noticeable characteristic.

\section{XYLORYCTIDE.}

Scieropepla (?) Photinodes, n.sp.

ㅇ. $22 \mathrm{~mm}$. Head and thorax blackish-fuscous, abdomen fuscous, segmental rings broad, reddish-ochreous, sides and under- 
side silvery-white, palpi fuscous, internally snow-white, terminal joint nearly 1 , basal joint slightly roughened externally. Anterior legs dark fuscous, coxæ sprinkled with white; posterior legs greyish-ochreous. Antennæ whitish, basal joint fuscous. Forewings elongate, costa strongly arched towards base, thence nearly straight, apex hardly pointed, hindmargin obliquely rounded; shining brassy-metallic, iridescent in some lights; a narrow snowwhite costal streak edged beneath with fuscous, from about $\frac{1}{3}$ to near apex, broadest in middle, attenuated at extremities; veins towards hindmargin outlined with dark fuscous; a large dark fuscous discal spot in middle at about $\frac{1}{3}$, preceded by a dark fuscous dot; a similar but smaller roundish spot in a line with the two preceding dots at about $\frac{2}{3}$; a suffused streak along inner margin throughout; all these markings more or less mixed with whitish scales: cilia shining fuscous, with a whitish basal line and a darker fuscous median line. Hindwings shining grey, lighter towards base; cilia grey-whitish, with a dark ochreous basal line, more pronounced round apex.

Hoyleton, S.A.; two specimens taken by Mr. E. Guest in Norember.

\section{GELECHIADES.}

\section{Gelechia platyleuca, n.sp.}

q. $17 \mathrm{~mm}$. Head, palpi, antennæ, thorax, legs, and abdomen dark fuscous, posterior legs greyish. Forewings elongate, moderate, costa gently arched, apex rounded, hindmargin obliquely rounded; dark fuscous; a broad white streak along costa from base to apex, attenuated at apex; an obscure narrow fuscous suffusion on extreme costal edge beyond middle: cilia dark fuscous, becoming lighter round anal angle. Hindwings dark fuscous, becoming lighter towards base; cilia fuscous.

Elizabeth Bay, Sydney, N.S. Wales; two specimens in October.

Gelechia porphyroloma, n.sp.

ઈิ-q. 15-18 mm. Head, thorax, antennæ, and palpi yellow, terminal joint of palpi except apex purple-fuscous. Legs fuscous, 
coxæ pale ochreous. Abdomen greyish. Forewings moderate, rather narrow; costa gently arched, apex round-pointed, hindmargin obliquely rounded; yellow; a purple-fuscous outwards-curved hindmarginal band from anal angle to costa near apex, becoming blackish on anterior edge, especially on lower $\frac{1}{2}$ : cilia greyishfuscous, becoming yellowish at base, in some specimens wholly yellow round anal angle. Hindwings and cilia grey.

Port Victor, S. Australia; five specimens in November.

It is nearest heliochrysa, Meyr., but with the thorax wholly yellow; it is not unlike Eulechria malacoptera, Meyr., an Ecophorid.

\section{GLYPHIPTERYGID压.}

\section{Glyphipteryx polychroA, n.sp.}

๙. $12 \mathrm{~mm}$. Head, antennæ, and thorax fuscous, palpi whitish with blackish rings beneath. Abdomen blackish. Legs fuscous. Forewings moderate, elongate, costa gently arched, hindmargin gently bowed; deep golden-ochreous; a curved dull whitishfuscous fascia, from $\frac{1}{6}$ costa to $\frac{1}{6}$ inner margin; a similar fascia from before $\frac{1}{3}$ of costa to $\frac{1}{3}$ inner margin, upper $\frac{2}{3}$ filled with metallic-coppery tint; two small metallic-coppery spots on costa, before and beyond middle; an ochreous-whitish tooth on costa before apex, with two or three connected metallic-coppery spots immediately beneath; an ochreous-whitish tooth at apex, followed beneath by a metallic-coppery dot-like hindmarginal line ending on a dense black elongate patch above anal angle; in the black patch are placed three coppery-metallic equidistant spots : cilia grey-whitish, basal half golden-ochreous. Hindwings dull goldenochreous; cilia greyish, basal half fuscous.

Melbourne, Victoria; one specimen in December.

In the iometalla group.

\section{LITHOCOLLETIDE.}

\section{LithocolLETIS DISMOCHRYSA, n.sp.}

אิ-o. 3-5 mm. Head, legs, thorax, and abdomen blackish, face and collar shining brassy-metallic, abdomen beneath sprinkled 
with brassy-metallic, especially on three anal segments, which become wholly brassy. Antennæ black, terminal $\frac{2}{3}$ white. Forewings narrow, apex acute, hindmargin obliquely rounded; black, with three equidistant golden-metallic straight fasciæ, 1st from $\frac{1}{3}$, 2nd from middle, 3rd from $\frac{3}{4}$ of costa, and all ending on inner margin; base of wing somewhat golden-metallic; a short inwardly oblique golden-metallic tooth at apex, reaching about $\frac{1}{2}$ across wing : cilia black, terminal half white. Hindwings very narrow, somewhat linear, blackish, thinly scaled; cilia six times as broad as wing, blackish.

Broken Hill, N.S. Wales; bred freely in March, from plants.

Mr. Meyrick, who kindly identified this and several of the other species mentioned in this paper, stated some time ago in the Proceedings of the Society that the genus Lithocolletis was unrepresented in Australia, but later he was able to describe a new species under the name of aglaozona, which at the time he remarked was not truly indigenous, as the larvæ were found feeding on a species of Desmodium, one of the Leguminosce, from which he inferred that the species was introduced with its food plant. In the present species it is a curious coincidence that the larvæ were first found by Dr. Blaxland feeding on Hardenbergia ovata, also one of the eguminosa, consequently I think that we have discovered a truly indigenous species, as it seems hardly probable (although possible) that the larva would feed on an indigenous plant, unless attached to the same. It may be an adaption to circumstances, but I hardly think so, as in close proximity were growing Cassia Brewsteri, and Hardenbergia pentaphylla, neither of which shewed any sign of the larva, whereas the food plant was attacked in a most prolific manner.

\section{PLUTELLIDE.}

\section{Plutella paracycla n.sp.}

ऊ-o. 22, $25 \mathrm{~mm}$. Head, palpi, antennæ, and thorax white; antennal ciliations 1 , second joint of palpi beneath fuscous, densely rough-haired, abdomen greyish, ochreous-tinged. Legs 
fuscous, posterior pair greyish. Forewings elongate, dilated posteriorly, costa gently and evenly arched, apex rounded, hindmargin extremely obliquely rounded; pale whitish-ochreous; costal edge pale ochreous throughout, except at base which is fuscous; a fine fuscous dot in dise at $\frac{1}{3}$, a second obliquely above and beyond; a moderate black dot at end of cell; a row of small black dots from just beneath costa at $\frac{4}{5}$ evenly curved around hindmargin and ending on anal angle : cilia rather broad, pale greyish-ochreous. Hindwings greyish; eilia as in forewings

Var. A. All markings obsolete, except dot at end of celi.

Broken Hill, N.S. Wales; four specimens in June.

\section{Notes on Synonymy.}

The following notes on synonymy have been compiled from personal inspection of the types. I am also indebted to Kirby's Catalogue of the Heterocera for several.

\section{RHOPALOCERA.}

\section{Ialmenus Dameli, Semp.}

Mus. Godf. Lep. xiv. 166, 1878.

I believe this species to be identical with the insect described by Dr. T. P. Lucas (Proc. Roy. Soc. Queensland, vi. 156, figs. 1-2, 1889) under the name of Ialmenus Illidgei, which Miskin considers to be a geographical form of ictinus, Hew., a decision however with which I disagree.

\section{Hesperilla dirphia, Hew.}

Descr. Hesp. p. 38, n. 2, 1868; Exot. Butt. v. Hesp. and Cyclop. f. 1-3, 1874: 今. Hesperilla trimaculata, Tepper, Trans. Roy. Soc. S.A. iv. p. 32, t. 2, f. 4, 1881 : . . Hesperilla quadrimaculata, Tepper, l.c. $t .2$, f. $2,1881$.

It will be seen that the male and female were described under different names. 
Pamphila gracilis, Tepper.

Trans. Roy. Soc. S.A. iv. p. 34, t. 2, fig. 7, 1882.

I am strongly of opinion that this species is identical with Hewitson's Astictopterus (Cyclopides) Cynone (Ex. Butt. f. 17, 1874). Unfortunately Mr. Tepper does not possess the type, but the balance seems in favour of Hewitson. The species is somewhat local and erratic in its appearance; my brother, Mr. Harold Lower, took it very commonly at the Semaphore, South Australia, in March.

\section{Hesperilla atralba, Tepper.}

Trans. Roy. Soc. S.A. iv. p. 33, t. 2, f. 5, 1881; Telesto dactyliota, Meyr., Proc. Linn. Soc. N.S.W. (2), ii. p. 831, 1887.

It will be seen that Tepper's name has priority.

Taractrocera flavovittata, Latr.

Hesperilla flavovittata, Latr., Enc. Meth. ix. 768, n. 114, 1819 : Apaustus (Ancyloxypha) agraulia, Hew., Descr. Hesp. p. 45, n. 3, 1868 ; Olliff, Ann. Mag. N.H. (6), i. p. 360, t. 20, ff. 3, a.b., 1888 : Pamphila sunias, Feld., Sitzb. Ak. Wiss. Wien, Math. Nat. Cl. xl. p. 462, n. 54, 1860 : Hesperilla bifasciata, Tepper, Trans. Roy. Soc. S.A. iv. p. 32 , t. 2, f. 4, 1881.

\section{HETEROCERA.}

Agarista albamedia, Lucas.

P.L.S.N.S.W. (2) vi. 301, 1891 : A. tetrapleura, Meyr., Trans. Roy. Soc. S.A. xiv. 194, 1891.

Agarista tropica, Lucas.

P.L.S.N.S.W. (2) vi. 302, 1891 : A. platyxantha, Meyr., Trans. Roy. Soc. S.A. xiv. 195, 1891.

The descriptions of Lucas and Meyrick were, as will be seen, both published in the same year; but I believe the Linn. Society's Proceedings were published first, consequently I assume Lucas's name has priority. 
Agarista contorta, Walk.

Cat. Lep. Het. B.M. p. 45, 1864: Agarista casuarince, Scott, Austral. Lep. i. p. 24, t. 8, 1865.

Agarista tristifica, Hb.

Eutactis tristifica, Hubn., Zutr. Ex. Schmett. i. p. 28, ff. 165, 166, 1818: Agarista Lewinii, Boisd., Voy. Astrolabe, Lep. p. 176, 6,1832 .

Porina australis, Walk.

Oxycanus australis, Walk., Bomb. 1574: Pielus maculosus, Feld., Reis. Nov. pl. lxxxi. 1: P. Kershawi, Lucas, P.L.S.N.S.W. (2) vi. $282,1891$.

Lithosia PRIstina, Walk.

Cat. Lep. Het. B.M. xxxv. p. 1885 (1866) : L. chionora, Meyr., P.L.S.N.S.W. (2) i. p. $702,1886$.

Calligenia placens, Walk.

Barsine placens, Walk., B.M. Cat. xxxi. 251, 1864: Calligenia cyclota, Meyr., P.L.S.N.S.W. (2), p. 705, 1886.

Calligenia melitaula, Meyr.

P.L.S.N.S.W. (2), i. 705, 1886 : Miltochrista simulans, Butl., Trans. Ent. Soc. Lond. p. 382, 1886.

Cluaca rubricosta, Walk.

B.M. Cat. 208, 1864: Castulo binotata, Walk., Char. Und. Lep. Het. p. 65, 1869.

Kirby places the species first in the family Lithosiidce (p. 298), and later in the Liparidae (p. 491), a rather misleading effort.

Philenora undulosa, Walk.

Acontia undulosa, Walk., Noct. 792 : Philenora undulosa, Ros., Ann. Mag. N.H. (5), xvi. 382, 1885 : Termessa Lyelliana, Lower, Trans. Roy. Soc. S.A., p. 148, 1893. 
Hectobrocha pentacyma, Meyr.

P.L.S.N.S.W. (2), p. 707, 1886 : H. multilinea, Lucas, op. cit. (2), iv. $1072,1890$.

Specimens of $H$. multilinea sent to me from Brisbane agree so well with the description of pentacymx that I have no hesitation in placing them together. Meyrick's species was founded on a single specimen.

Culama caliginosa, Walk.

Cossus caliginosus, Walk., B.M. Cat. 1522, 1856 : C. rhytiphorus, Lower, Trans. Roy. Soc. S.A. p. 147, 1893.

OnCOPtera Intricata, Walk.

Oncopera intricata, Walk., Bomb. 1559: Oncoptera intricata, Meyr., P.L.S.N.S.W. (2), iv. 1124, 1889.

An additional synonym is Hepialus fasciculatus, Walk., Char. Und. Lep. Het. p. 68, 1869.

\section{Ginosandra Boisduvalii, Newm.}

Enosandra Boisduvalii, Newm., Trans. Ent. Soc. Lond. (2), iii. p. 286, A pril, 1856 : Enosanda Duponchelii, Walk., l.c. p. 1713, May, 1856 : Teara (?) luctipennis, Walk., Char. Und. Lep. Het. p. $66,1869$.

Newman calls the genus Enosandra, and Walker Enosanda. $I$ adopt the former.

Darala varia, Walk.

B.M. Cat. iv. 890, 1855: . Colussa odenestaria, Walk., l.c. xxi. p. 288, 1860 : Darala succinea, Lucas, P.L.S.N.S.W. (2), vi. 290, 1891: Opsirhina tiutinarra, Tepper, Comm. Native Ins. S.A. p. $29,1890$.

Microdes squamulata, Gn.

x. 298: Oesymna stipataria, Walk., Char. Und. Lep. Het. p. $80,1869$. 


\section{Monoctenia vinaria, Gn.}

Enochroma vinaria, Gn. ix. 185, pl. vii. 2 : Balliace vetustaria, Walk., 290.

An additional synonym is Monoctenia decora, Walk., Char. Und. Lep. Het. p. 76, 1869.

$$
\text { Euchloris (Iodis) citro-limbaria, Gn. }
$$

Chlorochroma citro-limbaria, Gn. ix. 366 : Iodis Illidgei, Lucas, P.L.S.N.S.W. (2), iv. 603, 1889.

Euchloris (Iodis) metaspila, Walk.

Comibana metaspila, Walk., 580: Iodis eucalypti, Lucas, P.L.S.N.S.W. (2), iii. p. 1267, 1888.

Euchloris (Iodis) subalpina, Lucas.

P.L.S.N.S.W. (2), iii. p. 1264, 1888.

This is I believe identical with vertumnaria, Gn.

Phallaria ophiusaria, Gn.

An additional synonym is Smerinthus (?) Wayii, Tepper, Trans. Roy. Soc. S.A., v. 29, 1882. Kirby refers it to Colussa.

\section{Selidosema silicaria, Gr.}

An additional synonym is Tephrosia scitiferata, Walk., Ch. Und. Lep. Het. p. 77, 1869.

\section{Diastictis australiaria, Gn.}

An additional synonym is Macaria comptata, Walk., Ch. Und. Lep. Het. p. 78, 1869.

\section{Selidosema excursaria, Gn.}

An additional synonym is Tephrosic fulgurigera, Walk., Ch. Und. Lep. Het. p. 77, 1869.

\section{Metrocampa biplaga, Walk.}

Azelina biplaga, Walk., Char. Und. Lep. Het. p. 75, 1869 : Metrocampa glaucias, Meyr., P.L.S.N.S.W. (2), vi. 644, 1891. 
Mnesampela privata, Gn.

An additional synonym is Azelina inordinata, Walk., Ch. Und. Lep. Het. p. 75, 1869.

\section{Epipristis minimaria, Gn.}

Hypochroma minimaria, Gn., Phal. i. 279, 443, 1857: I/. parvula, Walk., B.M. Cat. xxi. 435, 1860 : Epipristis oxycymu, Meyr., P.L.S.N.S.W. (2), ii. 916, 1887.

Hypochroma nyssiata, Feld.

The insect figured in Reise Nov. Pl. Cxxv. 3, is I believe identical with Scceoptera marginalis, Walk., one of the Liparida, although the genus does not appear in Kirby's Catalogue of the Bombycina.

\section{Chlenias ochrosoma, Feld.}

The species figured in Reise Nov. Pl. cxxxI. fig. 30, appears to be identical with Guenée's Stathmorrhopa beggaria, the variety with ochreous-lined neuration of forewings.

Grammodes ocellata, Tepp.

Common Native Ins. S.A. p. 46, 1890: G. excellens, Lucas, P.L.S.N.S.W. (2) vii. p. 257, 1892; G. cyanopa, Meyr. (MSS.).

\section{Ophyx ochroptera, Gn.}

Noct. ii. 236, pl. 32, fig. i: Thermesia tenebrica, Lucas, Proc. Roy. Soc. Queensland, viii. p. 89, 1892.

\section{Stericta habitalis, Gn.}

An additional synonym is Acrobasis subcultella, Walk., Ch. Und. Lep. Het p. 81, 1869.

Semioceros murcalis, Walk.

An additional synonym is Samea distractalis, Walk., Ch. Und. Lep. Het. p. 73, 1869. 
Mecyna polygonalis, Hb.

An additional synonym is Tryphcena tineiformis, Tepp., Trans. Roy. Soc. S.A. v. 31, 1882.

\section{Nomophila noctuella, Schif.}

An additional synonym is Stenopteryx corticalis, Walk., Ch. Und. Lep. Het. p. 73, 1869.

\section{Capua obfuscatana, Meyr.}

P.L.S.N.S.W. vi. 455, 1881 : an earlier name for this species is intractana, Walk., (Sperchia intractana) Char. Und. Lep. Het. p. $82,1869$.

Cacecia postvittana, Walk.

An additional synonym is Dichelia vicariana, Walk., Ch. Und. Lep. Het. p. 82, 1869.

\section{Eulechria brachypepla, Meyr.}

P.L.S.N.S.W. vii. 524, 1882 : Zonopetala (?) stenoptera, Lower, Trans. Roy. Soc. S.A. p. 178, 1893.

\section{Glyphipteryx cyanochalca, Meyr.}

P.L.S.N.S.W. vii. 185, 1882 : G. Lyelliana, Lower, Trans. Roy. Soc. S.A. 182, 1893.

\section{Blabophanes meliorella, Walk.}

An additional synonym is Tinea niveibractella, Walk., Ch. Und. Lep. Het. p. 84, 1869.

Addenda :-

Teara ruptimacula, Feld.

Ochrogaster ruptimacula, Reis. Nov. t. 95, f. 9, 1874.

This I believe to be identical with Teara interrupta, Walk., B.M. Cat. 850, 1855. 
Deilephila livornicoides, Lucas.

Proc. Roy. Soc. Queensland, viii. p. 73, 1892.

This is simply a geographical form of the European livornica, Esp. I have taken specimens of this species at Adelaide, S.A., Moe, Victoria, and Broken Hill, N.S.W., and there is a variation in each and every specimen, but not sufficient to warrant a new species being formed. Lucas's types were from Queensland. I have seen a specimen bred at Adelaide from larvæ feeding on Lucerne (Medicago). 


\section{$2 \mathrm{BHL}$ Biodiversity Heritage Library}

Lower, O B. 1897. "Descriptions of new species of Australian Lepidoptera, with notes on synonymy." Proceedings of the Linnean Society of New South Wales 22, 10-32. https://doi.org/10.5962/bhl.part.12699.

View This Item Online: https://www.biodiversitylibrary.org/item/22896

DOI: https://doi.org/10.5962/bhl.part.12699

Permalink: https://www.biodiversitylibrary.org/partpdf/12699

\section{Holding Institution}

MBLWHOI Library

\section{Sponsored by}

MBLWHOI Library

\section{Copyright \& Reuse}

Copyright Status: NOT_IN_COPYRIGHT

This document was created from content at the Biodiversity Heritage Library, the world's largest open access digital library for biodiversity literature and archives. Visit BHL at https://www.biodiversitylibrary.org. 